This is an author produced version of a paper published in Urban Forestry \& Urban Greening. This paper has been peer-reviewed and is proof-corrected, but does not include the journal pagination.

Citation for the published paper:

Östberg, J., Martinsson, M., Stål, Ö. \& Fransson, F. (2012) Risk of root intrusion by tree and shrub species into sewer pipes in Swedish urban areas. Urban Forestry \& Urban Greening. 11:1, pp 65-71. http://dx.doi.org/10.1016/j.ufug.2011.11.001

Access to the published version may require journal subscription. Published with permission from: Elsevier

Standard set statement from the publisher:

NOTICE: this is the author's version of a work that was accepted for publication in Urban Forstry \& Urban Greening. Changes resulting from the publishing process, such as peer review, editing, corrections, structural formatting, and other quality control mechanisms may not be reflected in this document. Changes may have been made to this work since it was submitted for publication.

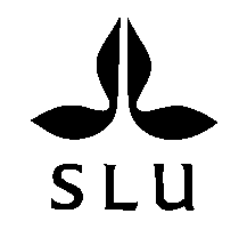

Epsilon Open Archive http://epsilon.slu.se 


\title{
Risk of root intrusion by tree and shrub species into sewer pipes in Swedish urban areas
}

\author{
Östberg Johan ${ }^{1 *}$, Martinsson Max ${ }^{2}$, Stål Örjan ${ }^{1}$, Fransson Ann-Mari ${ }^{1}$ \\ ${ }^{1}$ Swedish University of Agricultural Sciences, Faculty of Landscape Planning, Horticulture and Agricultural \\ Science, Department of Landscape Management, Design and Construction, Box 66, SE-23053 Alnarp, Sweden. \\ E-mail; Johan.Ostberg@slu.se, orjan.stal@slu.se, Ann-Mari.Fransson@slu.se \\ ${ }^{2}$ Serenity Solutions, computer software consultants, Lund, Sweden. E-mail; max@ serenity.nu \\ *Corresponding author
}

Keywords: Root intrusion; Pipes; Trees; Tree selection; PVC pipes; Concrete pipes

\begin{abstract}
Blockages in sewer pipes caused by roots are very common and several tree and shrub species are reported to be particularly likely to cause root intrusion. This study examined the relative ability of roots of different species to intrude into urban sewer pipes.

Data on root-intruded pipes and the woody plants surrounding these pipes were collected from two Swedish cities, Malmö and Skövde. Plant material, location data and closed-circuit television (CCTV) inspections on root-intruded pipes with a total length of $33.7 \mathrm{~km}$, containing 2180 different points of root intrusion, were examined. An inventory of 4107 woody plants was compiled.
\end{abstract}

The results showed that broad-leaved trees dominated as a cause of root intrusion, but that conifers and a number of shrubs, e.g. the genera Ligustrum, Spiraea and Syringa, were also likely to have caused root intrusion. Malus floribunda Van Houtte was found to have the highest mean share of root intrusions per estimated number of pipe joints when all joints and all root intrusions within a 10 $\mathrm{m}$ radius from trees were calculated $(0.694$, maximum number of intrusions per joint 1.0 ), while Populus canadensis 'Robusta' Moench had the second highest, with 0.456 intrusions per estimated joint. However, other Malus and Populus species and cultivars had a much lower mean share of root intrusions.

Most species seemed capable of causing root intrusion, and not only species of the genera Populus and Salix that were previously seen as the species most likely to cause damage to stormwater and sewer systems. There were differences in the frequency of joint intrusion by roots of different species, but the reasons for these differences were not identified and further research in the area is needed.

\section{Introduction}

There is often a conflict between tree roots and sewer pipes in the urban environment. According to a review by Randrup et al. (2001), up to $50 \%$ of all blockages in sewer pipes are caused by roots. In a survey in Denmark, $97 \%$ of towns and cities reported that their pipes had root intrusions (Randrup,
2000). In Sweden, the corresponding number was $99 \%$ of towns and cities (Stål, 1998). The most efficient action against root intrusion in pipes is probably chemical inhibition, which has been studied intensively (Leonard and Townley, 1971, Leonard et al., 1974, Groninger et al., 1997, Groninger and 
Bohanek, 2000 and Pohls et al., 2004). However, besides being hazardous, it is not a sustainable management strategy since the treatment does not have a permanent effect. Another disadvantage is that the method can only be applied when root intrusion has already occurred.

At present, pipes are in most cases laid in sections with joints. The number of joints is dependent on pipe dimensions and type of material, but most pipes are made of concrete and have a joint every metre. Although a new type of joint was introduced in the 1970s, joints are still the main entry point of roots (Ridgers et al., 2006).

It has been reported that older pipes made of concrete and clay are more susceptible to root intrusion than modern pipes made of PVC (Pohls et al., 2004 and Ridgers et al., 2006). Although root intrusion can occur in modern pipes, the majority of root intrusions are reported to occur in older pipes (Stål, 1998 and Ridgers et al., 2006).

Although there have been studies on root intrusion since at least the 1970s, there is a lack of data on non-chemical solutions to the problem. Many of the publications on root intrusion have not been published in peerreviewed scientific journals but as reports or as part of structural testing (e.g. Burn et al., 2000 and Bosseler et al., 2008). Swedish municipal authorities do not use chemical treatments to remove root intrusions and are thereby an important source of information on how to solve the problem of root intrusion in an alternative way. Being dependent on chemicals to deal with root intrusion can be a major problem if the use of chemicals is banned, especially since the problem is widespread (Stål, 1998 and Randrup, 2000).

Today, much money is spent on problems that are directly or indirectly caused by root intrusion, such as pipe-breaks, blockages, backflow and flooding. In Sweden, the cost of this was estimated to be SEK 55 million in 2003 (corresponding to EUR 5.6 million) (Orvesten et al., 2003). In Germany, an estimated EUR 28.4 million per year are spent on root removal and pipe replacement or renovations associated with root intrusion (Bennerscheidt et al., 2009).

An alternative way to overcome problems associated with root intrusion without the use of chemicals is to select woody plant species with a lower probability of causing root intrusion. Differences between tree species in their ability to cause root intrusion have been discussed frequently (Stål, 1992; Randrup, 2000; Randrup et al., 2001; Orvesten et al., 2003; Pohls et al., 2004; Streckenbach and Stützel, 2009). However, the potential problems with shrubs are rarely treated in the literature and the ability of shrubs to cause root intrusion is only mentioned briefly (Mattheck and Bethge, 2000; Pohls et al., 2004). It is reported to be primarily species that achieve a large leaf mass, require large quantities of water and have a high growth rate that cause root intrusions (Stål, 1992; Orvesten et al., 2003). According to Randrup (2000), the tree genera with the highest potential to cause root intrusion are Salix, Betula and Populus. Ridgers et al. (2006) also identified Salix and Populus as having a high potential to cause root intrusion. However, these identifications are only based on tree genera and species growing close to rootintruded pipes and are therefore affected by the frequency of planting of that species or genera at the specific site. For example, Pohls et al. (2004) found that Eucalypthus and Melalucea caused most root intrusions $(20.6 \%$ and $17.6 \%$, respectively) within 123 cities investigated in Australia. However, they noted that this might be due to the frequent use of these genera in the cities investigated. This might also be the reason why Salix and Populus are considered to have high root intrusion potential in Europe. Even ryegrass has been proven to cause root intrusion (Burn et al., 2000).

Although several inventories of trees and some shrubs causing root intrusion have been made (e.g. Mattheck and Bethge, 2000, Pohls et al., 2004 and Ridgers et al., 2006), no 
previous study has estimated the relative capability of different species to cause root intrusion. McPherson and Peper (1996) found that damage caused by the roots was the most frequently cited reason for discontinuing use of a tree species. Few studies have investigated the relative ability of species to cause root intrusion, including woody plants other than trees.

The main aim of this study was to compile a list of woody plant species and cultivars found around root-intruded pipes in Swedish urban areas and to estimate the probability of root intrusion by these species and cultivars. A second aim was to estimate and compare the ability of specific species and cultivars to cause root intrusion. A further aim was to examine whether there were any differences between the occurrences of root intrusion depending on the pipes construction material.

\section{Materials and methods}

\section{Cities}

In the Swedish cities of Malmö and Skövde, long lengths of pipes have been inspected with closed-circuit television (CCTV) and consequently these two cities were selected for this study. Large tree databases are also available for Malmö and Skövde. Malmö, the third largest city in Sweden, has a total of 285 514 inhabitants (Statistics Sweden, 2009) and is located in southern Sweden $\left(55^{\circ} 36^{\prime} \mathrm{N}\right.$, $12^{\circ} 59^{\prime} \mathrm{E}$ ). Skövde has a total of 50595 inhabitants (Statistics Sweden, 2009) and is located further north $\left(58^{\circ} 24^{\prime} \mathrm{N}, 13^{\circ} 50^{\prime} \mathrm{E}\right), 315$ $\mathrm{km}$ from Malmö. By selecting these cities, we accessed a large amount of data, which was crucial in calculating the probability of different woody plant species causing root intrusion.

\section{Pipes and CCTV inspection}

The number of root intrusion events in pipes and the location of each root intrusion were determined from CCTV inspection records. CCTV inspection is commonly used in studies on underground pipes, in particular sewage pipes (e.g. Bosseler et al., 2008, Tran et al., 2009 and Khan et al., 2010). During a CCTV inspection, a mobile camera is run through the pipe and the location of root intrusions and disparities is noted. The records from the inspections were used to determine the location of root intrusions for the present study. A root intrusion was defined as all points where it was noted in a CCTV inspection report that a root had penetrated the pipe. However the same root, if growing along the pipe, may have been recorded as two separate intrusions.

Data and CCTV inspections from root-intruded pipes with a total length of $33.7 \mathrm{~km}$ and with 2180 different root intrusions were examined, covering inspections from 1970 to 2007 . The cameras used also measure the distance from the entrance to the pipe and the location of the intrusion can thus be determined. Pipes located in woodlands were not analysed due to the large number of surrounding woody plants, which would have complicated the analysis. The data included were: pipe construction year, pipe material, pipe dimensions, and coordinates for the manholes and the root intrusions. All root intrusions were assumed to have come through joints or manholes, although some root intrusions may have come through service pipes or different defects, but this is only of minor importance for the results. The study focused on pipes constructed after 1970, since a new kind of artificial rubber seal designed to resist root intrusion was introduced at that time (Ridgers et al., 2006). In some cases the pipes had been CCTV-inspected several times, but only the first CCTV inspection that recorded root intrusion was included in this study.

In order to determine the proportion of joints that had suffered from root intrusions, the total number of joints within $20 \mathrm{~m}$ distance from a woody plant was estimated. The number of joints differs depending on the materials and dimensions of the pipes (Table 1). A small number of unknown pipes that are made of materials other than concrete or PVC, e.g. cast iron, clay and renovated pipes, were excluded from the study. 
Table 1. Number of joints per metre pipe for different pipe materials and dimensions and distribution of pipes of different types for the root-intruded pipes based on CCTV inspection data from the participating cities.

Distance between pipe joints Proportion of total pipe length (m) analysed in the participating cities $(\%)$.

\begin{tabular}{|c|c|c|}
\hline $\begin{array}{l}\text { Concrete pipes } 300 \mathrm{~mm} \text { in diameter } \\
\text { or smaller }\end{array}$ & 1 & $46 \%$ \\
\hline $\begin{array}{l}\text { Concrete pipes } 600 \mathrm{~mm} \text { in } \\
\text { diameter or larger }\end{array}$ & 1 & $8 \%$ \\
\hline $\begin{array}{l}\text { All concrete pipes between } 300 \\
\text { and } 600 \mathrm{~mm} \text { in diameter }\end{array}$ & 2 & $35 \%$ \\
\hline All PVC pipes & 6 & $7 \%$ \\
\hline $\begin{array}{l}\text { Other pipe types (e.g. cast iron and } \\
\text { clay pipes) }\end{array}$ & Unknown & $4 \%$ \\
\hline
\end{tabular}

Information on pipe material, dimensions, number of root intrusions and year of construction were obtained from the participating municipal authorities and the CCTV inspection company PULS (Swedish: Planerad Underhållsservice, English: Planned Maintenance Service, Staffanstorp Malmö, Sweden). Because of the large amount of data the material needed some corrections, which were made in close consultation with the municipal authorities and PULS, e.g. inaccurately recorded pipe materials and construction years.

\section{Tree and shrub inventory}

In 2008, species and location of 4107 woody plants were determined in the two cities. All woody plants within approximately $20 \mathrm{~m}$ from the root-intruded pipes were listed. Some larger trees were also included even though they were located outside the $20 \mathrm{~m}$ limit. The locations of these woody plants were determined using GPS. Perennials, newly planted shrubs and minor hedges were not included. Another 10445 trees from existing tree inventories in the cities were also included, so in total 14552 woody plants were included in this study. The trees from the existing inventories were within $40 \mathrm{~m}$ from the pipes. These data were used to identify individual trees with a high possibility of causing root intrusion. Accurate taxonomic identification of the species found was performed according to Aldén and Ryman (2009).

Although woody plants can grow long roots, up to $46 \mathrm{~m}$ long and $61 \mathrm{~m}$ deep according to Stone and Kalisz (1991), we chose 20 m from the root intrusion point as the maximum distance. At distances of more than $20 \mathrm{~m}$ from a root intrusion point, the uncertainty about the individual causing the intrusion becomes too large.

\section{Collection and organisation of information}

Digital maps and the tree data collected from the existing databases were transferred to a mobile computer (MobileMapper CE, Ashtech Company) where all the data from the tree inventory and the CCTV inspections were gathered. In order to analyse the large amount of data collected, a relational database (Postgre SQL, open source database system) and an interface to query the database were constructed. This relational database allowed us to determine the distance between root intrusions in the pipes and the location of the trees.

The coordinate system 'Non-Earth $(m)$ ' was used throughout the calculations. This system involves orthogonal coordinates and thus ignores the curvature of the earth, but since 
the study was confined to specific cities, this distortion was assumed to be negligible.

\section{Calculations}

The number of root intrusions per joint was calculated for all concrete and PVC pipes laid from 1970 up to 2007. The sum of all root intrusions was divided by all calculated joints for all pipes, which resulted in a maximum number of one root intrusion per joint.

In order to rank the probability of different tree and shrub species causing root intrusions, a two-step selection process was designed. Within $20 \mathrm{~m}$ from the pipes, a total of 186 different genera, species and cultivars were found. The first step thus aimed at narrowing down the list of woody plants to a manageable number. This was done by making a list of all woody plants standing within $10 \mathrm{~m}$ from a root intrusion without any other woody plant species or cultivars located within $20 \mathrm{~m}$ from that root intrusion. If any other trees or shrubs of another species were within $20 \mathrm{~m}$ from the root intrusion point, the tree or shrub was excluded. The same tree or shrub might have been selected more than once if it was within $10 \mathrm{~m}$ of more than one root intrusion point. As shown in Fig. 1, Tree $A$ was only selected if Tree B was of the same species and age. Tree $C$ was selected because it does not have any other trees or shrubs within the $20 \mathrm{~m}$ zone (Fig. 1). This step narrowed down the species list and also guaranteed that at least one of the individuals of that specific species or cultivar had a high probability of having caused a root intrusion.

The list was an important tool in creating a more comprehensive ranking of the probability of different species causing root intrusion. The species listed had a higher probability of causing root intrusions than many other species found within $20 \mathrm{~m}$ from the

pipes.

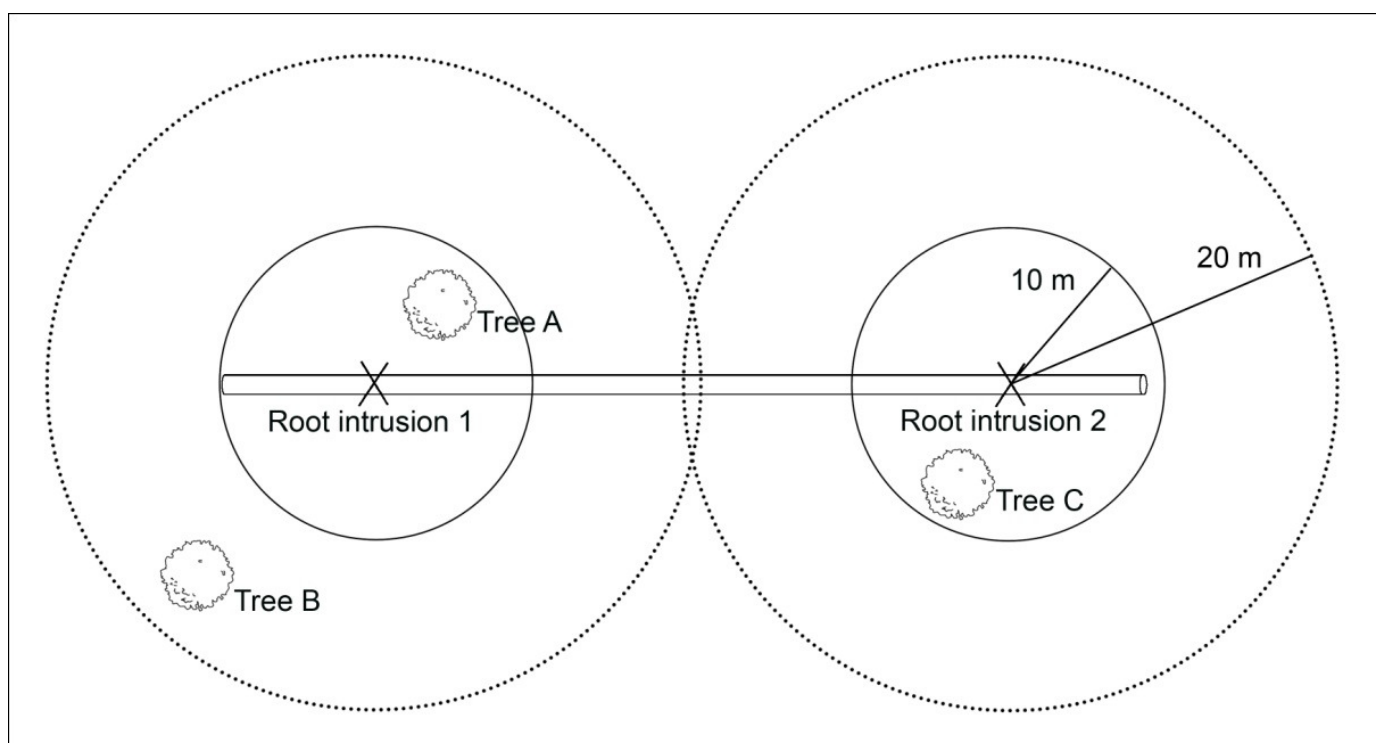

Figure 1. Selections made in order to identify trees with a high probability of causing root intrusion. All woody plants within $10 \mathrm{~m}$ from a root intrusion point were selected if there were no other trees or shrubs within $20 \mathrm{~m}$ from that point. Tree A was only selected if Tree B was of the same species and age, Tree C was always selected. 
This list of woody plants was then used to select the species and cultivars studied in the second step, when the number of root intrusions per available joint was calculated. The species list was hence used to select all woody plant individuals of that species or cultivar within $20 \mathrm{~m}$ from a pipe (Fig. 2). This allowed us to measure the number of root intrusions within $20 \mathrm{~m}$ from those individuals, and also how many joints were available to those individuals within the $20 \mathrm{~m}$ radius.

A circular area was calculated with a radius of $20 \mathrm{~m}$ from all individual woody plants belonging to the species and cultivars selected in the previous step, irrespective of their location relative to the pipes or root intrusions. All other species or cultivars that had not been selected in the previous step were hence excluded from further analysis. If no pipe was within this $20 \mathrm{~m}$ radius, the woody plants were excluded from the analysis. The total pipe length that was enclosed by the circles was calculated for all individual species. The likelihood of the different woody plants causing root intrusions was estimated by calculating the number of root intrusions per available joint of the pipes in the circular area (Fig. 2). If a joint had several root intrusions these were still counted as one single root intrusion, making the maximum number of root intrusions per calculated joint 1.0. It is important to note that the exact locations of the pipe joints were not determined and consequently the number of joints is an approximation.

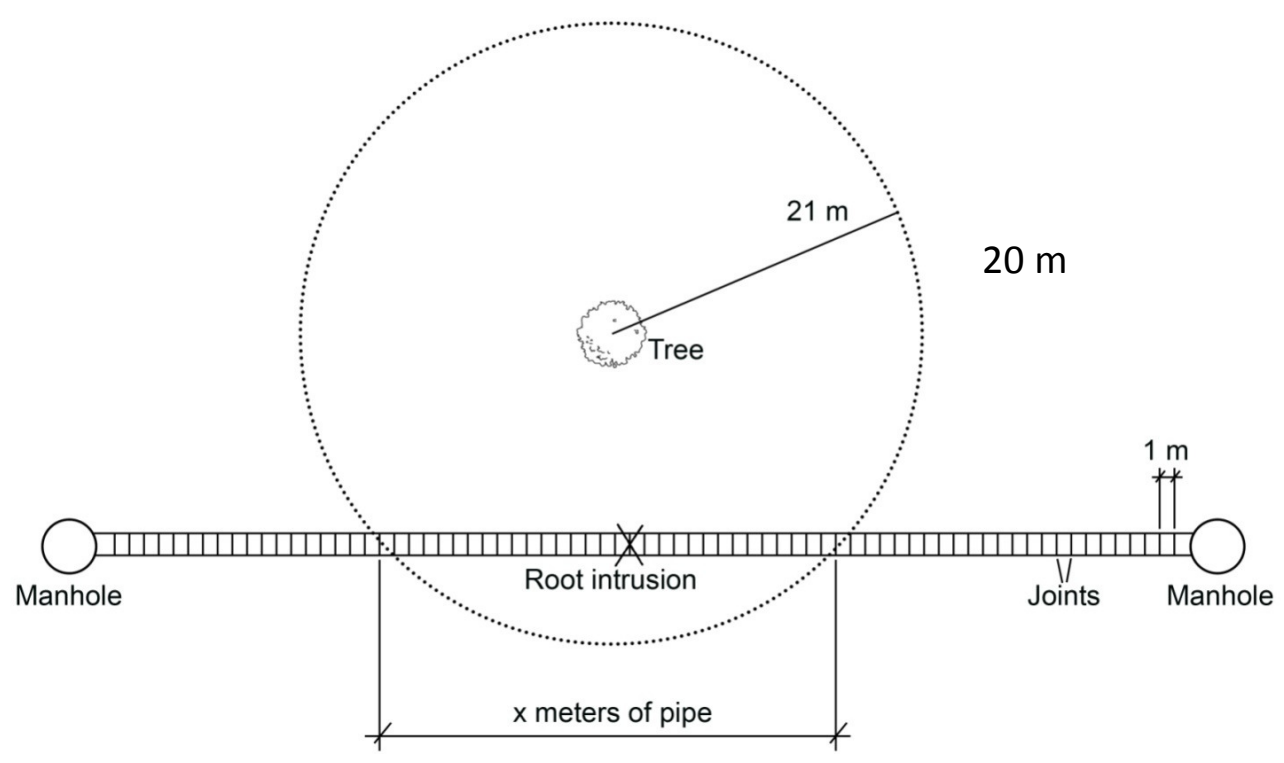

Figure 2. Illustration of the basis used for calculating the number of root intrusions per available joint and metre of pipe. All trees or shrubs with a pipe within a $20 \mathrm{~m}$ radius were selected. The number of joints per metre pipe was then used to calculate root intrusions by the individual tree or shrub per possible joint. In this case the tree caused one root intrusion per 31 joints ( 0.03 root intrusions per available joint). 


\section{Statistical analysis}

An independent t-test was performed on the number of root intrusions per joint and construction material for the different pipe materials, concrete and PVC $(p<0.05$, Minitab 15, Minitab Inc., Coventry, United Kingdom). A Kruskal-Wallis independent samples test was used to test the differences between all species root intrusion frequencies $(p<0.01$, IBM SPSS Statistics v. 19, Armonk, United States). A Chi-Square goodness of fit $(p<0.05$, Minitab 16) was performed to test significant differences in root intrusion frequencies between individual species. The mean value of all root intrusions per available joint $(0.216)$ was used to determine the deviation from the mean by the different species.

\section{Results}

The PVC pipes, with a mean number of 0.661 root intrusions per joint, had a significantly higher number of intrusions than the concrete pipes with its mean number of 0.080 root intrusions per joint $(p<0.00)$.

A total of 52 different woody plant species were identified as sole tree or shrub species. It was not only broad-leaved trees that caused root intrusion, as there were also a number of conifers, e.g. Juniperus and Thuja, present as sole woody plants close to root intrusion points. Among these plants were a number of shrubs likely to have caused root intrusions, e.g. the genera Ligustrum, Spiraea and Syringa.

All individuals belonging to these 52 species were used to calculate the root intrusion frequency per pipe joint. There were a total of 2421 individuals and significant differences ( $p$ $<0.01$ ) were found between species using the Kruskal-Wallis independent samples test. Significant differences were found for 48 of the species using the Chi-Square goodness of fit test (Table 2). Malus floribunda Van Houtte had the highest calculated mean of root intrusions per available joint (0.694), while Populus canadensis 'Robusta' Moench had the second highest, 0.456 intrusions per joint. This means that $M$. floribunda invades $69.4 \%$ of all joints it has access to within $20 \mathrm{~m}$. Thuja plicata D. Don had the lowest mean number of root intrusions per available joint (0.065) and Crataegus punctata Jacq. had the second lowest (0.091). However, these species still intruded $6 \%$ and $9 \%$, respectively, of joints within a $20 \mathrm{~m}$ radius. When woody plants with less than six individuals present were excluded, Crataegus laevigata DC. had the lowest mean number of root intrusions per available joint (0.115) and Sorbus aucuparia L. had the second lowest (0.116). This is almost half the mean number of all species $(0.216$ intrusions per joint).

In some cases there were large differences within the same genus. When comparing the genera containing more than two species, Malus had a range from 0.189 mean root intrusions per available joint for Malus domestica Borkh. up to 0.694 for $M$. floribunda. The genus Sorbus had the least internal deviation, with Sorbus aucuparia having the lowest mean value of 0.116 and Sorbus intermedia the highest mean value of 0.164 . 
Table 2. Mean number of root intrusions per available joint for the woody plant species or cultivars regarded to have caused root intrusions according to the steps presented in Figure 1, i.e. individuals within a $10 \mathrm{~m}$ radius from the root intrusion point and with no other individuals within $20 \mathrm{~m}$ from that point. The mean number of root intrusions per available joint was calculated according to Figure 2.

\begin{tabular}{|c|c|c|c|c|c|c|}
\hline Species & $\begin{array}{l}\mathrm{n}, \text { trees } \\
\text { within } 20 \\
\mathrm{~m} \text { from } \\
\text { pipe }\end{array}$ & $\begin{array}{l}\text { Mean } \\
\text { number } \\
\text { of root } \\
\text { intrusions } \\
\text { per } \\
\text { available } \\
\text { joint } \\
\end{array}$ & Std. dev. & $\begin{array}{l}\text { n, possible } \\
\text { joints }\end{array}$ & $\begin{array}{l}\text { n, root } \\
\text { intrusions }\end{array}$ & $\begin{array}{l}\text { p, Chi-Square } \\
\text { Goodness of } \\
\text { fit }\end{array}$ \\
\hline Acer campestre & 37 & 0.214 & 0.153 & 1285 & 191 & 0.000 \\
\hline Acer platanoides & 120 & 0.247 & 0.257 & 3984 & 705 & 0.000 \\
\hline Acer pseudoplatanus & 37 & 0.379 & 0.389 & 831 & 176 & 0.002 \\
\hline Aesculus hippocastanum & 55 & 0.192 & 0.149 & 2085 & 293 & 0.000 \\
\hline Betula pendula & 115 & 0.169 & 0.134 & 5055 & 776 & 0.000 \\
\hline Betula pendula Tristis' & 7 & 0.199 & 0.111 & 637 & 96 & 0.000 \\
\hline Betula pubescens & 62 & 0.130 & 0.068 & 2446 & 314 & 0.000 \\
\hline Carpinus betulus & 91 & 0.190 & 0.190 & 5133 & 701 & 0.000 \\
\hline Crataegus laevigata & 8 & 0.115 & 0.057 & 415 & 52 & 0.000 \\
\hline Crataegus punctata & 5 & 0.091 & 0.013 & 233 & 20 & 0.000 \\
\hline Fagus sylvatica & 17 & 0.380 & 0.451 & 648 & 108 & 0.000 \\
\hline $\begin{array}{l}\text { Fraxinus americana } \\
\text { 'Autumn Purple' }\end{array}$ & 5 & 0.151 & 0.059 & 93 & 14 & 0.032 \\
\hline Fraxinus excelsior & 61 & 0.189 & 0.198 & 1907 & 252 & 0.000 \\
\hline Juniperus spp. & 8 & 0.124 & 0.037 & 230 & 30 & 0.000 \\
\hline Kolkwitzia amabilis & 10 & 0.178 & 0.202 & 348 & 42 & 0.000 \\
\hline Ligustrum vulgare & 28 & 0.172 & 0.070 & 1370 & 220 & 0.000 \\
\hline Malus domestica & 55 & 0.189 & 0.265 & 1966 & 240 & 0.000 \\
\hline Malus floribunda & 11 & 0.694 & 0.569 & 234 & 99 & 0.000 \\
\hline Malus sargentii & 5 & 0.195 & 0.993 & 88 & 14 & 0.055 \\
\hline Malus spp. & 27 & 0.192 & 0.085 & 948 & 171 & 0.000 \\
\hline Platanus acerifolia & 42 & 0.413 & 0.297 & 1116 & 319 & 0.565 \\
\hline $\begin{array}{l}\text { Populus canadensis } \\
\text { 'Robusta' }\end{array}$ & 107 & 0.456 & 0.482 & 3398 & 1183 & 0.000 \\
\hline Populus simonii & 85 & 0.156 & 0.130 & 3097 & 400 & 0.000 \\
\hline Populus tremula & 37 & 0.123 & 0.056 & 1114 & 120 & 0.000 \\
\hline Populus tremula 'Erecta' & 12 & 0.208 & 0.135 & 382 & 50 & 0.000 \\
\hline Prunus avium & 54 & 0.209 & 0.186 & 1925 & 282 & 0.000 \\
\hline Prunus spp. & 48 & 0.177 & 0.144 & 1823 & 268 & 0.000 \\
\hline Pyrus communis & 13 & 0.160 & 0.158 & 514 & 59 & 0.000 \\
\hline Quercus robur & 37 & 0.197 & 0.220 & 1234 & 158 & 0.000 \\
\hline Salix alba & 379 & 0.237 & 0.235 & 13006 & 2570 & 0.000 \\
\hline Salix alba var. vitellina & 3 & 0.265 & 0.012 & 182 & 49 & 0.876 \\
\hline Salix caprea & 54 & 0.194 & 0.130 & 1911 & 337 & 0.000 \\
\hline Salix spp. & 76 & 0.202 & 0.133 & 3638 & 666 & 0.000 \\
\hline $\begin{array}{l}\text { Salix x pendulina } \\
\text { 'Elegantissima' }\end{array}$ & 16 & 0.164 & 0.171 & 431 & 47 & 0.000 \\
\hline
\end{tabular}




\begin{tabular}{lrrrrrr} 
Sambucus nigra & 14 & 0.146 & 0.102 & 487 & 58 & 0.000 \\
Sorbus aria & 37 & 0.148 & 0.152 & 1634 & 197 & 0.000 \\
Sorbus 'Astrid' & 7 & 0.120 & 0.038 & 356 & 40 & 0.000 \\
Sorbus aucuparia & 52 & 0.116 & 0.113 & 2221 & 210 & 0.000 \\
Sorbus intermedia & 47 & 0.164 & 0.100 & 1812 & 233 & 0.000 \\
Spiraea spp. & 52 & 0.220 & 0.197 & 2734 & 435 & 0.000 \\
\hline Syringa vulgaris & 60 & 0.148 & 0.133 & 2320 & 295 & 0.000 \\
Thuja occidentalis & 32 & 0.142 & 0.068 & 1105 & 142 & 0.000 \\
Thuja plicata & 4 & 0.065 & 0.026 & 137 & 8 & 0.000 \\
Tilia cordata & 26 & 0.365 & 0.357 & 943 & 174 & 0.000 \\
Tilia spp. & 45 & 0.179 & 0.135 & 1444 & 206 & 0.000 \\
Tilia x europaea & 52 & 0.266 & 0.385 & 1972 & 294 & 0.000 \\
Ulmus glabra & 106 & 0.226 & 0.234 & 3474 & 524 & 0.000 \\
Ulmus glabra & 19 & 0.446 & 0.317 & 720 & 205 & 0.676 \\
'Horizontalis' & & & & & & \\
Ulmus minor & 5 & 0.162 & 0.085 & 144 & 24 & 0.022 \\
Ulmus minor & 76 & 0.402 & 0.365 & 1746 & 533 & 0.038 \\
'Hoersholmiensis' & & & & & & \\
\hline Ulmus minor subsp. & 42 & 0.164 & 0.105 & 1389 & 184 & 0.000 \\
sarniensis & 18 & 0.190 & 0.176 & 383 & 53 & 0.000 \\
Ulmus spp. & $\mathbf{2 4 2 1}$ & $\mathbf{0 . 2 1 6}$ & $\mathbf{0 . 2 4 7}$ & $\mathbf{8 8 ~ 7 2 7}$ & $\mathbf{1 4 ~ 8 3 7}$ & \\
\hline Total/mean & & & & & & \\
\hline
\end{tabular}




\section{Discussion}

There seems to be a very large number of species that have the potential to cause root intrusion. To our knowledge, this is the first time the likelihood of root intrusion by different tree species has been calculated.

Our data indicate that most tree species can cause root intrusion and that shrubs and climbers also have the capacity to intrude into pipes. The results also present new insights into the variation that can be found within the same genus. Furthermore, they contradict some previous findings, since Orvesten et al. (2003) stated that Malus spp. have a low probability of causing root intrusion.

It was previously believed that fast-growing pioneer genera, e.g. Salix and Populus, were more likely to cause root intrusion than other genera (Randrup, 2000 and Ridgers et al., 2006). In addition, Randrup (2000) lists Betula as having a high risk of root intrusion, while Mattheck and Bethge (2000) list Quercus. The previous finding that slow-growing species, e.g. Malus baccata Borkh., and moderategrowing species, e.g.Tilia cordata Mill., do not cause root intrusion to such an extent as fastgrowing species (Stål et al., 2005) was not supported by the present study.

Some of the results and statements presented in previous studies regarding woody species that are the most troublesome in terms of root intrusion are not supported by our results. One of the most striking examples is $M$. floribunda, which caused the most root intrusions per pipe joint of all the woody plants included in this study. Malus is listed as the species with the lowest risk of root intrusion by Mattheck and Bethge (2000). On the other hand, the low risk of trees of the genus Malus is somewhat supported by $M$. domestica, which had below the mean number of root intrusions per available joint (0.189 root intrusions compared with the mean of 0.216 ). This shows that the number of root intrusions can differ greatly between species of the same genus.

Although this study contradicts some previously published conclusions, other findings were confirmed. Crataegus has been mentioned as a genus that very rarely causes root intrusion (Orvesten et al., 2003), and this was confirmed in the present study. It was also confirmed that $P$. canadensis 'Robusta' is one of the species most frequently causing root intrusion. However, there seem to be differences between different Populus species.

The inventories showed large numbers of Salix alba L. in Malmö. This overrepresentation of Salix may be explained by the presence of long avenues of pollarded S. alba in Malmö and by the fact that both Salix spp. and Populus spp. were popular in the 1960-1970s in Malmö, representing $3.9 \%$ and $6.1 \%$ of the total tree stock, respectively (Sjöman et al., 2011). This may have affected previous recommendations, which were often based on experience. This supports the claim by Pohls et al. (2004) that the overrepresentation of root intrusion by Eucalyptus spp. may owe more to planting frequency than actual root intrusion risk by this genus. However, this overrepresentation did not affect the present study, because the results presented are based on the mean number of root intrusions per available joint and not the number of individuals of a specific species close to a root intrusion. The calculations are based on the number of root intrusions that occurred within $20 \mathrm{~m}$ from the woody plants and the number of joints present within that $20 \mathrm{~m}$ radius.

We recommend that all woody plants be considered potential root intruders. In some extremely sensitive areas where no root intrusion can be accepted, no trees or shrubs should be planted. However, in most areas it has to be accepted that root intrusion could occur. Cooperation between city planners and civil engineers is needed to devise a management regime that reduces the damage caused by trees, as concluded in previous studies in Sweden (Orvesten et al., 2003; Östberg, 2008; Östberg et al., 2010)

Our data on the mean number of root intrusions per available joint should be viewed with some caution, as there were rather large differences between the number of root 
intrusions per available joint for different individuals within the same species or cultivar (large standard deviation). Although there were significant differences between the species $(p<0.001)$, it is likely that root intrusion is governed not only by tree/shrub species but also by other factors such as soil properties, distance between trees and pipes, pipe material, etc. (Bosseler et al., 2008). A previous study concluded that tree managers tend to view the problem with trees and different technical infrastructure as "siterelated involving interrelationships between tree species, tree growth and spatial requirements, and existing site limitations" (McPherson and Peper, 1995, p. 61). In the present case, site characteristics may also have been affected by differences in data collection between the two different cities. However, the fact that the data were collected in two cities makes the results more generally applicable.

Other possible factors influencing the risk of root intrusions were examined to some extent within this study by comparing the two pipe materials, concrete and PVC, and the construction years for these pipes. The high amount of root intrusions per joint for PVC can possibly be explained by these pipes mostly lying in shallow trenches, having a higher amount of service connections and drainage systems connected to them and being less common than concrete pipes in street environments, which results in a higher proportion of PVC pipes close to trees. However despite these possible explanations, there was still a significant difference between PVC and concrete pipes that must be recognised. This contradicts previous findings (Stål, 1998; Pohls et al., 2004; Ridgers et al., 2006). Although there are jointless pipes that offer protection against root intrusion, conventional PVC pipes with joints do not offer this protection.

Careful selection of species for planting close to pipes can influence the risk of root intrusion and by further studying the differences between species, a non-chemical solution to reduce the number of root intrusions might be identified. The results presented here have implications for cities such as Malmö, which will have to amend its recommendations on tree genera and species that should be avoided when planting near underground pipes (Trädplan för Malmö, 2005). Previous recommendations only mention that Salix and Populus species should be avoided, but other species such as $M$. floribunda can have a higher probability of causing root intrusion.

Many questions on the underlying causes and progress of root intrusion into sewer pipes remain to be answered. This study is the first example of large-scale data collection being used to provide statistical evidence of differences between woody species in their ability to cause root intrusion. However, more research is needed to confirm these results and to make solid recommendations on species that can be used to reduce the risk of root intrusion.

\section{Acknowledgements}

This study was carried out in cooperation with Svenskt Vatten (VA-Forsk), Partnership Alnarp, J. Gust. Richert Foundation (SWECO), PULS AB, Tekis AB, Inpipe, Per Aarslev, NCC Ledningsrenovering, City of Malmö, City of Katrineholm, City of Skövde and City of Växjö. Bengt Mattsson and Ewa Kjellman at PULS AB, and Arne Mattsson at the City of Malmö contributed both practical and theoretical knowledge. Many thanks to the municipalities where the research was conducted, as without their support this study would not have been possible. The authors also want to thank Hanna Fors and Björn Wiström for the illustrations.

\section{References}

Aldén, B., Ryman, S., 2009. Cultivated Plant Names (Våra Kulturväxters Namn). Formas, Stockholm, (In Swedish).

Bennerscheidt, C., Stutzel, T., Strechenbach, M., Schmiedener, H., 2009. Unterirdische Infrastruktur - Bauteile, Bauverfahren and Schäden durch Wurzeln, in: Deutsche Baumpflegetage 2009 (D. Dujesiefken, ed.), Haymarket Media GmbH \& Co. KG, Augsburg, pp. 23-32, (In German).

Bosseler, B., Stützel, T., Bennerscheidt, C., 2008. Root penetration in sewers: Causes, 
tests and prevention, in: COST Action C15 Improving relations between technical infrastructure and vegetation, COST office, Alnarp.

Burn, L.S., Lu, J.P., Whittle, A.J., 2000. Elastomeric joint performance of PVC, VC and FRC pipes. Polymer Engineering \& Science 40(10), 2217-2226.

Groninger, J.W., Bohanek, R.J., 2000. Effects of diquat applied to exposed roots of black willow. Journal of Plant Growth Regulation 19(4), 453-456.

Groninger, J.W., Zedaker, S.M., Seiler, J.R., 1997. Herbicides to control tree roots in sewer lines. Journal of Arboriculture 23(5), 169-172.

Khan, Z., Zayed, T., Moselhi, O., 2010. Structural condition assessment of sewer pipes. Journal of Performance of Constructed Facilities 24(2), 170-179.

Leonard, O.A., Bayer, D.E., Glenn, R.K., 1974. Control of tree roots. Weed Science Society of America 22(5), 516-520.

Leonard, O.A., Townley, N.R., 1971. Control of tree roots in sewers and drains. California Agriculture 25(11), 13-15.

Mattheck, C., Bethge, K., 2000. Biomechanical study on the interactions of roots with gas and water pipelines for the evaluation of tree sites. Arboricultural Journal 23(4), 343-377.

McPherson, G., Paula, P., 1995. Infrastructure repair costs associated with street trees in 15 cities, pp 49-63. In: Watson G.W. and D. Neely (Eds.) Trees and Building Sites: Proceedings of an International Workshop on Trees and Buildings. International Society of Arboriculture, Champaign, IL.

McPherson, G., Peper, P., 1996. Costs of street tree damage to infrastructure. Arboricultural Journal 20(2), 143-160.

Orvesten, A., Kristoffersson, A., Stål, Ö., 2003. Trädrötter och ledningar - goda exempel på lösningar och samverkansformer. VA-Forsk $\mathrm{nr}$ 31, Stockholm (In Swedish with English summery).
Östberg, J., 2008. Samarbetsrutiner vid rotinträngningar: en jämförande studie mellan Malmö, Skövde, Katrineholm och Växjö. Alnarp: SLU. Examensarbeten inom Landskapsingenjörsprogrammet vol. 2008:12, (In Swedish).

Östberg, J., Stål, Ö., Martinsson, M., Fransson, A-M., 2010. Förebyggande av rotinträngningar i VA-ledningar - utveckling av beslutsstöd. Stockholm: VA-Forsk $\mathrm{nr}$ 4, (In Swedish with English summery).

Pohls, O., Bailey. N.G., May. P.B., 2004. Study of root invasion of sewer pipes and potential ameliorative techniques. ISHS Acta Horticulturae 643: International Conference on Urban Horticulture, pp. 113-121.

Randrup, T., 2000. Occurrence of tree roots in Danish municipal sewer systems. Arboricultural Journal 24(4), 283-306.

Randrup, T., McPherson, G., Costello, L., 2001. Tree root intrusion in sewer systems: Review of extent and costs. Journal of Infrastructure Systems 7(26:6), 26-31.

Ridgers, D., Rolf, K., Stål, Ö., 2006. Management and planning solutions to lack of resistance to root penetration by modern PVC and concrete sewer pipes. Arboricultural Journal 29, 269-290.

Sjöman, H., Östberg, J., Bühler, O., 2012. Diversity and distribution of the urban tree population in ten major Nordic cities. Urban Forestry and Urban Greening 11(1), 31-39.

Stål, Ö., 1992. Trädrötter och ledningar. Alnarp: Stad \& Land. Movium, (In Swedish).

Stål, Ö., Rolf, K., Ridgers., 2005. Trädrötter och ledningar - nya rön om rotinträngningar $i$ moderna VA-ledningar. VA-Forsk $\mathrm{nr}$ 11, Stockholm (In Swedish with English summery).

Stål, Ö., 1998. The interaction of tree roots and sewers: The Swedish experience. Arboricultural Journal 22(4), 359-367.

Statistics Sweden, 2009. Retrieved September 10, 2009 from www.scb.se: http://www.scb.se/Pages/Product___ 12991. 
aspx?produktkod=MI0810\&displaypressreleas e=true\&pressreleaseid=226686.

Stone, E., Kalisz, P., 1991. On the maximum extent of tree roots. Forest Ecology and Management 46(1-2), 59-102.

Streckenbach, M., Stützel, T., 2009. Durch Wurzel verursachte Schäden an Rohrleitungen und vergleichtbaren Bauwerken, in: Deutsche Baumpflegetage 2009 (D. Dujesiefken, ed.), Haymarket Media GmbH \& Co. KG, Augsburg, pp. 41-51, (In German).
Trädplan för Malmö, 2005. Trädplan för Malmö. Malmö Centraltryckeri AB, Malmö, (In Swedish).

Tran, H.D., Perera, B.J.C., Ng, A.W.M., 2009. Predicting structural deterioration condition of individual storm-water pipes using probabilistic neural networks and multiple logistic regression models. Journal of Water Resources Planning and Management 135(6), 553-557. 